\title{
French Farce: Printing, Dissemination and Readership from 1500-1560*
}

\author{
CHRISTOPHER PINET
}

The short, comic plays known as farces, most popular in France from 1450-1550, are best known and usually studied as a literary genre. Most critics have dwelt on thematic questions, character types such as the farce lover, the cuckolded husband and the lecherous monk, the different kinds of farce, stylistics and language structure. ${ }^{1}$ (There is little information on performance.) The fact that many, indeed most of them, were printed and sold has either been ignored or treated as unimportant. ${ }^{2}$ Even the noted historian of printing, Henri-Jean Martin, has suggested the main reason farces were printed was because of the collecting interests of private individuals intent upon preserving a disappearing genre. ${ }^{3}$ Thus, few writers have included farce among the popular vernacular literature that began to flow in increasing quantities from the printing presses of Paris, Lyon and Rouen in the early sixteenth century. ${ }^{4}$

A further reason for the neglect of the role of farce in the revolution in communications caused by the advent of printing is that, until recently, literary critics and historians have assumed that most of the supposed spectators of farce, namely the "menu peuple," were illiterate. Since few printed farces have been found in the private libraries of sixteenth-century Frenchmen, critics have concluded that the farces were not intended to be read or more printed copies would remain. Consequently, there has been little attempt to link French farce with the advent of printing and its impact on literacy, reading habits, and cultural values in sixteenth-century France or its relationship to the transition from oral to print culture.

Any studies on the functions and uses of farce which ignore its status as printed text give an incomplete picture of its role in sixteenthcentury France. A reexamination of the questions of printing, dissemination and readership of farce will shed further light on the impact

* The author wishes to acknowledge research grants from the Indiana State University Research Committee and the Marquette University Committee on Research which made possible the archival work done in Paris and the completion of this article. 


\section{2 / Renaissance and Reformation}

of the invention of printing on these popular plays as well as show their role as a catalyst in increasing literacy from 1500 to 1550 and beyond. This reexamination is rooted in a variety of primary and secondary materials. The first are the printed farces themselves and the chronology of their printing as part of a larger body of popular vernacular literature. It is in the texts that we find direct reference to their distribution. Secondly, confirmation of the printing and sale of large quantities of the plays comes both from the pioneer work of Eugénie Droz and my own exploration of the unpublished fiches of Philippe Renouard on Parisian printers of the sixteenth century. ${ }^{5}$ As for readership, the recent archival research by historians, Natalie Davis and George Huppert among others, has resulted in new views on what constituted literacy in sixteenthcentury France and on how people, including the poorer segments of society, learned to read both in and out of Catholic and public colleges as well as petty and choirboy schools, and even hospitals. ${ }^{6}$ Finally, a close look at the mnemonic elements present in farce will show how these texts served as informal or unexpected primers for learning to read in early modern France. It should then be possible to suggest some of the ways in which farce, while continuing the earlier oral tradition of the fabliaux by presenting spoken language in printed form, serves as a bridge between oral and print culture. ${ }^{7}$

One of the problems in establishing the case for farce as part of the printed popular literature of the sixteenth century has been the small number (150-200) of extant farces (the number grows to about 400 if we include sotties and moralities, monologues, sermons and dialogues). Approximately 75-80 percent of them survive in printed texts and many in the long, narrow agenda format which was common to all popular vernacular literature (probably because it was easier to fit into a peddler's bag), including broadsides, all printed in inexpensive Gothic type. ${ }^{8}$

There are good reasons to believe that there were more farces written, printed and sold. For example, in 1585 the bibliophile DuVerdier wrote in his Bibliothèque françoise, "On ne sauroit dire les farces qui ont été composées et imprimées si gran en est le nombre. Car au temps passé, chascun se mesloit d'en faire."9 In addition to this contemporary's comment, Louis Petit de Julleville lists fifty-nine pièces comiques for which the texts have been lost, but for which there is evidence of their existence. ${ }^{10}$ Henri-Jean Martin has further hypothesized about what may have happened to the plays and why so few of them were accounted for in the inventories of booksellers:

Many books, and especially plays, were obviously tied up together in bundles, in which case the bookseller would undoubtedly content himself with giving only the title of the work on top of the pile. These very tempting 
hypotheses would account for many such absences - that of Pathelin, Villon, and the farces and mystery plays at the beginning of the sixteenth century, and during the seventeenth century. I myself studied the seventeenth-century inventories and found no mention of Astrée or Grand Cyre, nor of Corneille, Racine or Molière; this suggests to me that the owners of these big libraries, after 1560, being mostly lawyers, part humanist and part scholar, considered themselves much too serious-minded to bother with trivia of this nature. ${ }^{11}$

Natalie Davis assumes that the plays were printed and that there was a market for them: "Farces, moralities, and mysteries were pouring from the presses of Paris and Lyon in the first part of the sixteenth century...." (p. 200) Support for her assertion can be found in the work of Eugénie Droz on the printers and publishers of the Recueil Trepperel (named for the Parisian printer Jehan Trepperel), one of the extant printed collections of farces, moralities and sotties. ${ }^{12}$ Droz claims that most farces were printed and published in series which possibly represented the entire theatrical repertoire of the publisher. Her rationale is that farces, sermons, moralities and sotties were often performed on the same programme; thus, in a printed series the spectator could find all the plays and might follow along during the performance (Droz, p. XLII). Indeed, the actors themselves may very well have held reference copies while onstage. It is fortunate that these series were bound, or we would probably have even fewer extant texts. The fact that many were serially printed attests to the financial considerations of the printers and publishers who found it cheaper to prepare a large quantity of paper in the agenda format and to set type for more than one play at a time (Droz, p. XLIV).

Droz found fourteen series containing 150 plays. This led her to conclude that certain publishing houses in Lyon, Paris (and I would add Rouen) specialized in popular plays and even competed among themselves for the urban market (Droz, p. LXII). This conclusion is supported by the fact that the printers, publishers and booksellers she cites spanned some 60 years and, in some cases, succeeded one another in the same printing establishment, inheriting presses, type and the texts of their predecessors. ${ }^{13}$ In Paris, for example, Pierre Le Caron was printing farce-like dialogues and moralities in the vernacular after 1494 and before 1500 , so that printed popular literature exists as incunabula, a much earlier beginning than is usually attributed to printed vernacular literature in any quantity. Jehan Trepperel, of course, is the best known of the printers who specialized in popular drama, and he and his widow, in association with Jehan Jehannot, worked out of a shop "En la rue neufve Nostre, à l'enseigne de l'escu de France" from 1504-1525. Pierre Sergent worked in the same shop from 1532-1547 and was succeeded 
by Nicolas Chrestien at this locality from 1547 to 1557 . In Lyon the best known printers were Claude Davout (ca. 1510) and Jean Cantarel (known as Motin), who was active from 1532 until about 1550. Finally, Jehan le Prest printed farces in Rouen between 1542 and 1559.

This sixty-year span for the printing and publishing of vernacular plays suggests that they were successful as a commercial venture which would have been impossible had there been no readers. Barbara Bowen has shown that they continued to be reedited into the seventeenth century. ${ }^{14}$ This pattern should come as no surprise, however, since we know that mystery plays, moralities, farces and sotties were established as part of a medieval French dramatic tradition that predated the introduction of printing in France and was well established in the fifteenth century. Printers wasted no time in exploiting this popularity and some began to shift their attention from Latin texts to vernacular literature even by the sixteenth century. The new market for printed vernacular literature paralleled demands by theatre-goers for plays performed in French. In fact, Louis Petit de Julleville reports that when, in 1502, a comedy by Terence in Latin was given in the episcopal palace at Metz, the audience of clerics and townspeople attacked the actors when they realized that they would not understand what was going on, and the play had to be stopped. ${ }^{15}$

With increased demand for both performances and texts in the vernacular, it is possible that printing changed the pattern of public entertainment by making it profitable for a troupe to sell its text(s) to a printer who then sold his product to the public at fairs and in the marketplaces where the plays were often performed. In addition, publishers often sent out peddlers (colporteurs). Thus, the actual sale of plays might also have served to announce the arrival of a troupe in a community. The printer might have furnished the players with acting copies free of charge. The plays were printed rapidly and proofs were not always corrected, which accounts for the printing errors and omissions found in the extant printed texts. ${ }^{16}$

If, as Droz suggests, there were printers and publishers who specialized in popular drama, the field was not limited to a few specialists; the market seems to have been profitable enough for other printers and publishers to add the plays to their lists. As Robert Darnton says, "Books are economic commodities as well as cultural artifacts; and as vehicles of ideas they have to be peddled on a market."17

By looking closely at the unpublished fiches of Philippe Renouard on sixteenth-century Parisian printers, it is possible to show who some of these printers were and how they came to print popular drama. For example, there is Michel Le Noir, a bookseller and printer who is best known for having published many shortened versions of medieval 
romances during the first twenty years of the sixteenth century. According to A.H. Schutz, these books were destined for the middle classes, including merchants, lawyers and others who owned private libraries. ${ }^{18}$ But Le Noir also published some short dramatic works including $L a$ Complainte de trop tost marié on September 28, 1509, and an undated edition of Pierre Gringoire's Fantaisies du monde. The Complainte is similar in title and theme to other farces and dialogues of the period while Gringoire was a well-known popular dramatist whose criticism of Pope Julius XII won him favour with Louis XII (Droz, p. LXX). One of Le Noir's sons, Pierre, continued to print farces and sotties after his father's death in 1520. Among these works are several editions of the Menus Propos de mère sotte by Gringoire, a monologue by Guillaume Coquillart, a number of debates, and two editions of Maistre Pierre Pathelin, the best known farce of the late medieval period and perhaps the most frequently printed. ${ }^{19}$

Jean Longis was another bookseller-printer who published many volumes of vernacular literature. Mlle. Droz names him in a footnote for having published an edition of the Roman de la Rose in 1538 (p. L). The notarial inventories show that this was among the most frequently printed of the books found in the private libraries of the time. ${ }^{20} \mathrm{How}$ ever, Longis also published Contreditz du Prince des Sotz autrement dit Songecreux in 1532, the works of Coquillart in the same year and Le Débat des deux gentilzhommes in 1541. The printing of the works of Coquillart would seem to be an index of their continued popularity since Trepperel had published them at a much earlier date. More interesting still is that the title page indicates that the works of Coquillart (in Gothic type in this edition) were sold in Paris for Galiot du Pré "en la grant salle du Palays." This is significant because du Pré had one of the biggest bookselling businesses in Paris at this time. ${ }^{21}$

There is also Alain Lotrian, a bookseller-printer who worked on the "Rue Neuve" and printed dialogues and works by Gringoire, undated but probably printed between 1518 and 1540. Such was also the case with the Apologie des Chamberieres qui ont perdu leur mariage and the Débat de l'homme et de l'argent, the first of which sounds much like a farce, judging by its title. Lotrian also printed Les Menus Propos avec le temps qui court which contains popular sayings and proverbs. Some of these chronicle the times; one of them even talks of one of the gates in Paris, "la porte Baudais," which is also the title of a farce. ${ }^{22}$ The refrain reads, "Il fut bien fondé en raison/Le droit de la port Baudais." A number of the sayings ridicule monks, a common theme in farce, and others tell of adulterous women, also a popular subject of farce. In addition to the proverbs, Lotrian also published popular contemporary songs.

One of the most striking facts about the printers, publishers, book- 
sellers and merchants discussed above is that none of them seems to have specialized in popular drama and yet all of them must have found it profitable to print and sell the plays. But how did they discover what plays to sell? Rudolph Hirsch has established that printers commonly began with a varied program of titles, producing traditional titles side by side with what he calls "innovations." 23 Thus, someone like Jean Longis, a bookseller who had tremendous success with the French translation of l'Amadis de Gaule as well as with the Roman de la Rose, could try to expand his market and sales by adding popular plays to his successful list of prose romances. ${ }^{24}$ This suggests that there were numerous middle-class readers for farce and that this readership spurred further production.

If Longis's publishing practices link farce to middle-class readers, there is other evidence that links it to broadsides or "bulletins d'information" which contained news and were often illustrated (farces usually were not) and destined for more of the menu peuple. What one discovers is that Pierre Le Caron, Guillaume Nyverd, Guillaume Bineaulx and the Rouennais Jehan le Prest, all listed by Droz as printers of popular drama, printed broadsides as well. ${ }^{25}$ This was also true of Alain Lotrian. This is important first because Jean-Pierre Seguin has shown that these news sheets were widely circulated. Second, they resemble popular plays in their format: "Les pièces d'actualité sont, matériellement, à la fin du $\mathrm{XV}^{\mathrm{e}}$ siècle, de petites brochures étroitement semblables par leur format, leur papier, leur composition, leur épaisseur, aux pièces populaires en langue française de la même période." ${ }^{26}$ Once again, we have evidence of early circulation of popular literature. The news-sheets varied in length from two to fourteen folio pages but were usually from four to six pages. The longest, of fourteen folio pages, would be about the same length as the average farce of four hundred octosyllabic lines. In fact, Seguin says that "extérieurement, les pièces d'actualité ne se distinguent des poésies, complaintes, farces et autres petites pièces contemporaines que par un certain souci des imprimeurs de choisir des bois ayant plus souvant au moins quelque rapport avec le sujet traité." 27 The newssheets were discovered bound to other volumes of popular literature; this suggests that they may have been sold with popular plays from the same bags or stalls or made to resemble them in order to increase sales.

As for subject matter, it varied from optimistic accounts of the military campaigns of Charles VIII in Italy (these publications were officially sanctioned and thus served as an early form of propaganda) to descriptions of spectacular events and ceremonies such as royal entries with commentaries in prose and verse. Although not plays, some of them, on the basis of their content and simple vocabulary, were clearly destined for the same marginally literate reading public as farce. A number of the accounts of the wars in Italy are presented as dialogues, 
a mnemonics which is the same as that of farce. They, like farces, were printed with Gothic type. Seguin states that there was competition between printers with each trying to make his news-sheet more attractive than his competitors'. This competitive aspect parallels Droz's hypothesis about the practices of specialists in printed popular drama. With the advent of the poste system in 1518, it seems possible that some farces made it into the same bag as the officially sanctioned newssheets.

At least one other link between news-sheets and farces exists, and it is related to an account in a news-sheet of a procession in Lyon in July 1530 entitled "La grant triumphe faicte des Nobles Princes Monsieur le Daulphin et le noble duc Dorléans et de la Royne ma dame Alienor. ..." It reads as follows: "Et durant ladicte procession, a este joué parmy les rues comédies, facéties et fainctises si très illustrement que jamais filz dhomme ne vit ni ne ouyt parler de telles entreprises." ${ }^{28}$ This description makes it seem possible that farces were being sold to the same people who would later buy news-sheets describing the performance of the farce which they had seen and perhaps bought on the occasion of a royal procession where many people were gathered together. Equally possible is that, as in this case, a printer's broadside might serve as publicity for farces that the chapmen peddling news-sheets were carrying in the same bags. In other words, if we can imagine the peddler advertising broadsides by quoting the lines given above, we can also imagine him adding words to the effect, "And if you want to find out how funny those plays were, why I just happen to have some copies here in my bag!"

This hypothesis about how popular drama was advertised is not so far-fetched as it might seem at first glance; there is considerable evidence in the plays themselves that substantiates it. Consider the farce $L e$ Vendeur de Livres et Deux Femmes. ${ }^{29}$

A chapman opens the play with the following cry:

Livres, livres, livres!

Chansons, balades et rondeaux!

J'en portes a plus de cent livres.

Livres, livres, livres!

Venez tost que je vous en livres:

Jamais n'en vistes de sy beaulx

Livres, livres, livres!

Chansons, balades et rondeaux!

La farce Jenin aux fiseaux,

Le testament maistre Mymin,

Et maistre Pierre Patelin

Et les Cent Nouvelles Nouvelles

Pour dames et pour damoyselles

Qui ayment a passer le temps (11.1-14). 
Later, the peddler adds la grand Farce des Femmes qui on la langue arse quand y blasonnent leurs maris, (11.63-66), la farce Jehan Loysson (11.128-129) and le Testament Pierre Maistre (11.128-129), probably a reference to le Testament Pathelin. Not only does the ambulatory peddler or colporteur have a cry as did most of the tradesmen of the time, but he refers to specific farces which were undoubtedly familiar to those within earshot or in the audience during the performance of the play. ${ }^{30}$ Thus, the cry might serve the same purpose in performance as in real life. For a given peddler, the cry would vary depending on the people to whom he was trying to sell books. What we see confirmed here, however, is the popularity of a play like Pathelin, at least twenty editions of which appeared between 1490 and 1553 and seven between 1561 and $1614 .^{31}$ Mimin, whose name figures in the titles of at least three extant farces, one edition of which was printed in Paris and one in Lyon, was also a great favourite. "Jehan," commonly used to mean cuckold or fool, also figures in many farces either in the title or as a character. We also know that Les Cent Nouvelles Nouvelles had numerous editions. On the other hand, the other farces listed have not survived, although la grand Farce des Femmes. . . could be another title for La Femme mute alluded to by Rabelais. ${ }^{32}$

This example of publicizing one's wares, in this case books, is not unique in popular drama; Philipot tells of another play, Fin ruby de Turquie, where the street vendor lists Pathelin as one of the items he had sold during his career. ${ }^{33}$ Les cent et sept cris que l'on crie journellement à Paris. De nouveau composé en rhimme françoise pour resjouir les esperits, published by Anthoine Truquet in 1545, gives us a further idea of the plays hawked by street sellers:

Beaux A.B.C. en parchemin, Le premier livre des docteurs!

Tandis que je suis en chemin

A qui en vendra-je un ou deux?

Prognostication nouvelle,

Beaux almanachz nouveaux.

Ilz sont aussi bonne que belle

Que ceux de maistre Jean Thibaut!

Livres nouveaux!

Chansons, balades et rondeaux!

Le passetemps Michaut!

La farce du mau marié

La patience des femmes

Obstinées contre leurs maris! $!^{34}$

The mau marie seems to be lost, although the theme of the unhappily married husband is common in farce as we have seen in the case of $L a$ 
Complainte de trop tost marié, printed by Michel Le Noir. ${ }^{35}$ There is a play entitled L'Obstination des Femmes which dates from the end of the fifteenth century and may be the one referred to in the last two lines of the "cry." ${ }^{36}$ It is also interesting to note that the ABC books or early primers were sold by the same peddlers who sold farces. Some possible parallels between the two will be explored later along with the role of songs in farce.

Yet another reference to the sale of popular literature can be found in the sottie, Des Coppieurs et Lardeurs qui sont copiez et farcez, dated by Droz as before 1480. ${ }^{37}$ A brief review of Droz's discussion of the plays listed in this sottie should demonstrate further how references to plays within a play might serve as a form of advertising for printers, publishers, booksellers, authors and actors alike. The sottie takes place in the boutique of Malostru, a copier of books, presumably printed ones. The discussion of farces occurs when Teste Creuse proposes that the other characters play an old farce. Seeing books open in Malostru's shop, Sotin asks what they are. In addition to the Dance de Macabré par parsonnaiges, the Basse dance "nouvelle" and Rosty boully, two of the most popular contemporary songs, Malostru also gives the following farces: Farce de Pathelin, Poitrasse, Pouvre Jouhan. But Sotin claims that they are too old and a discussion follows where other farces are suggested:

Malostru: Voullez vous farce d'eschauffault?

Teste Creuse: Nenny

Malostru: Farce de nopces?

Sotin: Jamais

Malostru: Ou de collieges?

Teste Creuse: Pour tous metz,

Nous demandons farce de bande

Malostru: Vostre cause très bien s'amende, La Fillerie est bonne farce.

Sotin: Nous n'en voullon point de si grasse.

Malostru: J'ay la Farce des troys coquins.

Teste Creuse: Ce sont ouvrages trop badins;

Nous demandons jeux plus nouveaux.

Malostru: Ha, j'ay la Farce des oyseaulx

Esse chose de bien?

(Malostru)

Teste Creuse: C'est baulme

(Droz, pp. 164-165, 11. 173-185)

Pathelin's importance has already been discussed. Pauvre Jouhan is part of the Recueil Trepperel as is the sottie in which it is cited. So, 
perhaps Trepperel himself was trying to advertise other plays in his own repertoire. There is no record of Poitrasse; the title could be an invention of the author much as are some of the prose romances named by Rabelais in the Prologue to Gargantua. Nor is there any record of La Fillerie. However, the Trois Coquins is part of the Recueil Trepperel and is listed as Sotz gardonnez. Droz has also found an unpublished farce entitled des Coquins à cinq personnages (p. 181). Finally, the Farce des Oyseaulx is also known as Farce de la Pipée and is listed by Petit de Julleville in his Répertoire. . ( p. 148). One play, Le Testament Ragot, printed by Guillaume Nyverd, gets to the point in the title page: "Achetes lay et le payes comptant." 38

There is, then, considerable evidence of the printing of farces, and the plays themselves abound in advertising slogans and lists of popular farces sold by peddlers, all of which suggests a wide-spread pattern of sales and readers. But, beyond the better educated middle classes of the urban areas, who were these readers and who could, after all, read in early modern France? And what, in any case, did farce have to do with learning to read?

The question of readership for farce does not seem to be related to social class. Bowen has shown that farces were performed at court in the second half of the sixteenth century as well as being reprinted, and Martin's arguments offer an explanation of their absence from notarial inventories. ${ }^{39}$ Also, the texts show that peddlers sold them along with prose works like the Cent Nouvelles Nouvelles, prose romances, and almanacs which are listed in the notarial inventories. This suggests that the plays were printed and probably written with a variety of readers in mind. ${ }^{40}$ Thus, one must reject the notion that the plays were sold only to one social class or set of readers. Darnton makes this point about eighteenth-century popular literature in quoting the work of Daniel Mornet to the effect that "reading tastes did not correlate closely with social status." 41 The same point, of course, could be made about Gothic romances or pornography today, much as Nykrog showed that the often pornographic and obscene fabliaux were read to aristocratic as well as bourgeois audiences. ${ }^{42}$ One ought, nonetheless, to be able to discover readers from among the lower socio-economic groups that lived in urban areas, references to whom abound in the farces. Until recently such a task would have been thought impossible because it was assumed that most artisans were illiterate in the sixteenth century. Reasons given for this include the fact that instruction in the colleges or grammar schools was entirely in Latin and that even in the "petty" schools Latin was taught first so that if one did not already know how to read and write French one would not only be at a disadvantage, but there was no guarantee that one would learn to read and write in the 
vernacular at all. ${ }^{43}$ Recently, however, new archival research, especially that of George Huppert, has shown that public education, with classes conducted in French, did exist in the early sixteenth century, and that it predates Jesuit education, which, according to Father Dainville and others, was first responsible for increased literacy on a large scale. In fact, Huppert believes that municipal collèges, or grammar schools, played a dominant role in early gains in literacy. In reference to Dainville's work he states, "What is absent from all these researches is any awareness of the municipal colleges which grew up everywhere in the kingdom and effectively dominated French education for a century until they foundered or were taken over by the Jesuits." $44 \mathrm{He}$ also says that "it is not really unusual to find tanners, vintners or laboureurs who manage to send a son off to school, even to faraway and expensive Paris." 45 Huppert has also shown that some of the actual texts used in the classroom were in French (for example the "abécédaires" or ABC books), and that vernacular reading teachers were provided by most of the municipal colleges. ${ }^{46}$ These new data help to confirm Rudolph Hirsch's assertion that a new class of readers was developing after the advent of printing: "...the majority of new readers was recruited among children who formerly did not go to school, among women, and among the economically less favored classes. It was for them that most of the simple, easily readable texts were issued: books of piety, calendars, news-sheets, propaganda, indulgences, books telling how to bring up the young, etc." 47 To this list we must now add farce, although it is not possible to prove that farces were used in the classroom.

Natalie Davis has discussed the important role of municipal colleges in Toulouse, Nimes and Lyon in the first half of the sixteenth century (1530's and 1540's) in increasing literacy, although they excluded girls (p. 73). Such exclusion was also true for what she describes as "... . most of the little vernacular schools that mushroomed in even quite modest city neighborhoods during these years" (p. 73). This would seem to confirm that some schools specialized in the teaching of reading and writing of French at an early date, and Dainville has shown that the ages of the children in a given class might vary, making it seem possible that young men working as apprentices or journeymen might also be attending classes to learn how to read, a point made by Natalie Davis about classes in hospital schools. ${ }^{48}$

In addition to the municipal colleges, petty schools, and chantries, hospitals provided similar opportunities to learn to read and write in French to urban dwellers and specifically the poor. Classes were set up at two hospitals for poor orphans and foundlings by the AumôneGénérale in Lyon (Davis, p. 55). Davis describes their role: "The boys were taught to read and write, and so were a few of the girls with the 


\section{2 / Renaissance and Reformation}

ability and inclination. Bright orphan boys were sent free of charge to the municipal Collège de la Trinite, where they might mix with the sons of the well-to-do" (pp. 42-43). Another facet of the program was that "Most of the male orphans were apprenticed to artisans at the expense of the Aumône, sometimes in highly skilled trades - printing, smelting, painting, sword gilding, embroidering and the like" (p. 42). Not only did such a programme widen the range of the literate urban populace, but it increased the chances for advancement of the participants and helped to initiate literacy within the trades. ${ }^{49}$ We know, of course, that in England guilds had played an early role in educating their members. ${ }^{50}$

These early formal attempts to educate more people received added impetus with the advent of the Reform and Luther's famous exhortation to municipal officials to establish more schools, made in 1524: "Vous le comprenez, il nous faut à tous lieux des écoles pour nos filles et nos garçons afin que l'homme devienne capable d'exercer convenablement sa profession et la femme de diriger son ménage et d'élever chrétiennement ses enfants. Et c'est à vous, seigneurs de prendre cette oeuvre en main, car si l'on remet ce soin aux parents, nous périrons cent fois avant que la chose se fasse." 51

While it is beyond the scope of this article to investigate the impact of the Reformation on increased literacy and education, a subject much studied already, Natalie Davis and Robert Kingdon both show that the Reform Movement helped in converting urban tradesmen, especially printers, to Protestantism through the widespread dissemination of printed Bibles and psalters. ${ }^{52}$

Concern for learning to read was also expressed by humanists interested in spreading the use of the vernacular. This was true of J.L. Vives, whose De trandendis disciplinis, published in 1531, reads as follows:

The man desirous of wisdom must make use of books or of those men who take the place of books .... . Let a school be established in every township, and let there be received into it as teachers men who are of ascertained learning, uprightness and prudence. Let their salary be paid to them from the public treasure.... Let the teacher know the mother tongue of the boys exactly, so that by means of their vernacular he may make his instruction easier and more pleasing...; the teacher should keep in mind the earlier history of his mother-tongue. ${ }^{53}$

Any of the official paths to literacy described above would have made it possible for anyone to read a popular play. This is made clear in one of the plays printed by Jean Longis, Le Débat de la vigne et du laboureur: "Ceulx qui ont hanté les escoles/Les liront en lieu dune espitre." 54 Whether or not vernacular plays were taught in the schools 
as part of the curriculum we do not know, but these verses make it appear possible. Certainly vernacular plays were performed by schoolboys. ${ }^{55}$

In spite of the many possible ways in which someone might have acquired a modicum of schooling, many if not most of the urban artisans probably received no formal training in reading, and yet would appear to have possessed the rudiments necessary for reading farces. Chartier suggests that informal education was the norm in the sixteenth century: "Pour la majorité, du laboureur à l'artisan mais aussi au gentilhomme et souvent au procureur ou au prêtre de campagne, l'éducation hors l'école reste la règle." 56 But what did this extra-curricular learning consist of? How exactly did the urban dwellers learn to read if, in fact, they did? Natalie Davis has suggested some of the ways in which this elementary learning took place. Davis first defines which people in the cities were likely to be affected by printing: "In the cities this means the small merchants and the craftsmen (masters and journeymen) and even semiskilled workers (such as urban gardeners and fishermen) having some connection with urban organizations such as confraternities and guilds. It means their wives, themselves ordinarily at work in the trades, and even women in the families of the wealthier merchants. It means domestic servants, male or female, who might be living in their households. It does not include the unskilled dayworkers, the gagnedenier and manouvriers, the portefaix and crocheteurs, the vagabonds and permanent beggars" (pp. 193-194). The ways in which these individuals learned to read centred on the reading aloud of books by someone in a primary group - family, guild or religious gathering - or a cleric reading to members of his parish or a Protestant assembly where the Bible was read aloud (pp. 213-214). I would suggest that such rudimentary learning might also take place at the performance of a farce or morality play where a beginning reader might follow along in the text. ${ }^{57}$ It does seem clear that one had to have some ability to read and write to belong to the more advanced trades where business was done with written accounts. Using ability to sign as one index of literacy, Davis shows that this ability "ranged from high among groups like printers, surgeons and goldsmiths, to moderate among men in the leather and textile trades, to low - although still well above zero - among men in the food and construction trades." (pp. 72; 209-210) Later she adds tavern and metal workers to the high category and artisans in the textile and clothing trades to the moderate group (pp. 210, 214). Although the step from signing to reading may have been a large one, the spread of literacy in the trades is not really surprising when we consider that in England schools were established as early as the thirteenth century by certain guilds and that in the early fifteenth century the Goldsmiths Company 
"levied fines... on any members who failed to have their apprentices taught to read and write and who refused at the same time to take on apprentices who could not do so." 58

Although most artisans did not own books at their deaths, they did represent 10 percent of all bookowners in Paris in the sixteenth century (Davis, p. 211). On the other hand, artisans had other access to printed books. As Davis says, "They bought a book, read it until they were finished, or until they were broke or needed cash, and then pawned it with an innkeeper or more likely sold it to a friend or libraire" (p. 212). This would certainly have been true of farce and other popular drama which was primarily for entertainment. Lending was another way in which books circulated.

In addition to group readings, Elizabeth Eisenstein has suggested that in the period following the introduction of printing many individuals probably taught themselves to read: "With the duplication of primers and alphabet books, a new element of self-selection entered into the acquisition of literacy. The autodidact like the printer himself was a new kind of self-made man - one who was necessarily set apart from his unlettered parents or forebears." 59 Thus, in the sixteenth century one learned to read in a variety of ways and on a variety of levels and these variously trained people furnish part of the readership for farce and other popular drama. But why farce? What makes it or other popular drama more accessible to readers than, say, prose romances?

There are, in fact, many aspects of farce which make it especially accessible and suitable as material for beginning readers. Foremost is the predominance of the oral or popular spoken language (Droz, p. LXX). This is important for it meant that the printed text reproduced a vocabulary and expressions already familiar to the beginning reader as speaker. Further, since in many cases this reader might have already seen the play performed, the actual sounding out of the letters, syllables, words and then word-chains would be greatly facilitated. This sounding out was a reading aloud or, as H.J. Chaytor says in From Script to Print, "The medieval reader was in the stage of our muttering childhood learner. he whispered to himself when he found the solution."60 The solution was made easier by the familiarity of the language of farce. The reader might have had the text in hand while watching the performance so he would have been able to follow along. Ong's statement that "In an oral culture, verbalized learning takes place in an atmosphere of celebration or play...." also applies to learning to read farces. ${ }^{61}$

Speaking and reading are complementary activities in the learning process, and farce, by presenting an essentially oral vocabulary, served to bridge the gap in this process. Present-day researchers in learning theory, such as Robert M. Gagné, have emphasized the interdependency 
of the two activities and insist that "oral repetition" is a necessary part of learning to read "because it is so obviously a skill subordinate to the pronunciation of printed words, thus, the ultimate achievement of decoding printed words has a branch concerned with 'speaking' that is just as essential as the branch concerned with 'symbol identification." " 62 In this sense, printed farce in its earliest texts was essentially a transcription of oral performance and dialogue and depended on the orality or oral memory of beginning readers to make sense of the words. ${ }^{63}$ The new reader was "on familiar ground," as Walter Ong says in a related context. ${ }^{64}$ Indeed, this is one of the reasons why printed farces were popular, that is, the individual was seeing in print what he might have just heard, said or done.

But there are other features of farce which made it accessible to the ever-growing number of readers in urban areas; they include a variety of mnemonic devices or memory aids that give farce some of the characteristics of early primers. Foremost among these is the octosyllabic verse (with rhyming couplets of the pattern aabb) which typifies farce. Droz claims that this rhyme scheme was chosen because it made memorization easier for the actors; it is also clear that it helped the beginning reader to remember what he had seen and heard in performance or while listening to someone else read the text. That people learned to read by listening first to others and that this is not a complex process cannot be overemphasized, for as Schofield states with reference to vernacular literature generally, "In such a situation, it only needs one or two members of normally illiterate groups who have acquired an ability to read, to read aloud to their friends and neighbours, for a bridge to be thrown across any supposed divide between exclusively literate and illiterate groups within society."

Davies has pointed out the importance of rhyming couplets in promoting literacy in England in the sixteenth centliry and cites one book in particular which is very much like the Cris de Paris already discussed. Published by Alexander Lacy in 1562 to teach children to read, the book is entitled $A$ Book in English metre of the great merchant man called Dives Pragmaticus, very pretty for children to read, whereby they may the better and readier read and write wares and implements in this world contained. The goods are shouted out so that the children can learn to "read and write the occupations, tools and commodities that are being advertised." 66 The goods mentioned include the following:

I have to sell carpets, chests, coffee and locks,

Presses and keys, wheels, spindles and rocks,

Pig, goose and capons, hens, chickens and cocks,

What wares do you lack? Come hither to me. ... 
I have here to sell fine needles and thimbles, Nail piercers, small pod chisels and wimbles, Blades, and for weavers fine shuttles and brimbles. What do you lack, friend? Come hither to me... .

Honest mirth in measure is a pleasant thing:

To write and read well be gifts of learning.

Remember this well, for all you that be young,

Exercise virtue, and rule well your tongue. ${ }^{67}$

These verses are much like the "cris" and monologues that begin so many farces.

Rhymes were not limited to drama, however, and Natalie Davis has shown that the manual Brief Arithmetic promised to teach a tradesman all he needed to know in fifteen days and added mnemonic verses to help him learn (p. 213). The full title of the work was Art et science de arismetique moult utille et profitable a toutes gens et facille a entendre par la plume et par le gect subtil pour ceulx qui ne scavent lyre ne escripre (p. 332, footnote 62). The first edition of the book was published by Trepperel's widow and Jean Janot around 1520. Trepperel, of course, had specialized in farces, sotties and other popular drama, all in octosyllabic verse. Henri-Jean Martin has shown that the Trepperels and Janot published a variety of other how-to manuals, probably destined for the same public as that of farce: "A Paris, les le Noir multiplient les romans de chevalerie dans des éditions moins somptueuses que celles de leurs prédécesseurs. Surtout les Trepperel et Jean Janot lancent une série d'ouvrages ou voisinent Traité de cuisine, Questionnaire des chirurgiens et barbiers, Noëls et chansons, Traité des rues et églises de Paris avec les cris de Paris, vie de saint Fiacre, histoires de Maguelonne et de Merlin, Trésor des pauvres enseignant l'art de se soigner économiquement ou Vies des trois Marie." ${ }^{68}$ Martin might also have included farces, sotties and moralities in his list, since we know that Trepperel printed them. It also seems plausible that the fatras included in the inventory of the Parisian bookseller Guillaume Godard, prepared in 1548 and studied by Annie Charon-Parent, of which there were 10,283, in addition to a thousand sheets of ABC books, might well have included farces. ${ }^{69}$ Albert Labarre has found similar references to the sales of fatras in his book on Amiens. ${ }^{70}$

In addition to rhymes and spoken language, farces also included popular proverbs, songs, refrains and the "cris" already discussed, all of which served as further mnemonic devices, not only because they contained rhymes but because they brought to farce many of the elements of contemporary life experienced by those who read them. The inclusion of numerous songs in farce has been documented by Howard Mayer Brown in Music in the French Secular Theatre; he found over one 
hundred and twenty songs or fragments of songs in the nearly four hundred plays (including moralities, monologues and sotties as well as farce). ${ }^{71}$ As for the context of the songs, Brown observed that "... a character is often discovered onstage singing at the very beginning of a play" (p. 83). Although a given song is not always related thematically to the play itself, it would nonetheless have served as a memory-aid for a semi-literate person trying to recall the plot-line, since he would probably have known the song already; the song would have served as a "way in" to the rest of the play, a short-cut to correlating the printed characters with the appropriate sounds. These songs also ended the plays and Brown has shown that the characters sing where people would in daily life, that is, while working and while selling their goods, using the street cries discussed above. It is important to note here that the printing of the plays and the songs in them probably affected how they were performed and changed the scope of public entertainment as both readers and spectators developed greater sophistication. As Elizabeth Einsenstein says, "The printing of poems, plays, and songs altered the way 'lines' were recited, sung and composed... A literary culture created by typography was conveyed to the ear, not the eye, by classroom lectures, repertory companies, and poetry-readings." 72 In the early stages of the printing of popular drama the influence on the printed text of the existing oral culture was as great as that of the new invention in developing a language of print.

Natalie Davis has shown how the singing of Protestant songs served to attract printers to the Reform Movement, and Elizabeth Eisenstein has noted that this influence crossed the boundaries of literate and illiterate printers: "The illiterate journeymen ... sang songs composed by Marot and Beza which were circulated in printed form."73 Robert Kingdon has also documented the importance of the vernacular psalter for Protestant congregations. ${ }^{74}$ The printed farces, on the other hand, attracted new readers.

The proverbes en rimes and other rhyming verses, such as boutsrimés, coqs à l'asne, and refrains, are discussed in detail by Barbara Bowen, although less as mnemonic devices than as dramatic ones used to highlight comic moments. ${ }^{75}$ Natalie Davis suggests that common proverbs served the religious purposes of preachers by making a sermon's message easier to remember as well as for learning French; printed editions of them appeared in Lyon and Paris in the 1490's and were bought by schoolteachers and lawyers (pp. 232-233; 235). In fact, one of the main reasons for the extent of mnemonics in farce must be to make the plays easier to understand and identify with, both as performed and printed drama. This, combined with the "français fondamental" of the dialogues, made them especially suitable for beginning readers and complemented legal moves to expand the use of French. ${ }^{76}$ 
Although it is not possible to prove that the printed texts of farces received widespread use in the schools, this survey of farce as printed popular literature does suggest a number of ways in which printing transformed its purposes and extended its social functions, although not always consciously. There is no question that farce served to increase the literacy of beginning readers through the presence of many mnemonic devices; this "readability" in turn acted to increase the standardized use of French, a process already under way in the first half of the sixteenth century. The printing of the plays also served to preserve many aspects of popular culture by fixing them in print and made them available to other, more elite groups which in turn modified and made the literature their own, much as was the case for popular proverbs and later Perrault's contes. ${ }^{77}$ Insofar as farce and other popular drama reflect the religious tensions between Protestants and Catholics, the printed texts also serve to transmit new ideas that include criticism of the Catholic Church and her representatives and practices.

Finally, by successfully competing in the marketplace as an economic commodity, farce served not only to entertain growing numbers of people but to prepare them to read more difficult matter which allowed them to cope better with a rapidly changing society while preserving their ties to the essentially oral traditions and customs of an earlier time.

\section{Marquette University}

\section{Footnotes}

1 The best known of the more recent book-length studies are the following: Barbara Bowen, Les Caractéristiques essentielles de la farce française et leur survivance dans les années 15501620, Illinois Studies in Language and Literature, No. 53 (Urbana: University of Illinois Press, 1964) and Halina Lewicka, Etudes sur l'ancienne farce française (Paris: Klincksieck, 1974). This second work groups ten of the author's earlier articles which have been modified to reflect further research or changes in her views.

2 The one notable exception to this is Eugénie Droz, who in her "Introduction" to Le Recueil Trepperel, Les Sotties (Paris: Librairie E. Droz, 1935), pp. XI-LXXIV and especially pp. XXXII-LXIII, was the first to study the printers of popular drama, including farce. Her work has served as a point of departure for the present study. Further page references to it will be included in the text.

3 Professor Martin originally proposed this to me in a conversation in 1970. Judging by his latest article, "Culture écrite et culture orale, culture savante et culture populaire dans la France d'ancien régime," Journal des Savants, octobre-décembre, 1975, pp. 225-282, M. Martin has not changed his view. Cf. pp. 232-233 \& 240.

4 Natalie Z. Davis, Society and Culture in Early Modern France (Stanford: Stanford University Press, 1975), p. 200. Without attempting to explain how it was so, Professor Davis has nonetheless (correctly in my view) assumed that farces were printed in large quantities in Paris and Lyon in the first part of the sixteenth century. This was also true of Rouen. 
5 Madame Jeanne Veyrin-Forrer of the Réserve of the Bibliothèque Nationale kindly provided me access to the "fiches Renouard" which are located in the Réserve.

6 Natalie Z. Davis, Society and Culture in Early Modern France, p. 209. Further references to Professor Davis' invaluable work on popular culture will be included in the text. Professor Huppert first presented his ideas on schools at the Central Renaissance Conference (March $28-30,1974$ ) in a paper entitled "Public Schools in Renaissance France" and kindly allowed me to use his footnotes as supporting evidence for the argument presented in this article. Since then, Professor Huppert has published Les Bourgeois Gentilhommes: An Essay on the Definition of Elites in Renaissance France (Chicago: University of Chicago Press, 1977). His chapter on schools gives a full account of the ideas outlined here.

7 See Walter Ong, The Presence of the Word (New Haven: Yale University Press, 1968) for a general discussion of the shifts from oral to print culture. See also his article, "The Writer's Audience Is Always a Fiction," PMLA, 90 (1975) 9-21.

8 Halina Lewicka, Le Recueil du British Museum, Fac-Similé des Soixante-quatre pièces de l'original (Geneva: Slatkine Reprints, 1970), pp. X-XI.

9 Quoted from Louis Petit de Julleville, La Comédie et les moeurs en France au Moyen-Age (Paris: L. Cerf, 1886), pp. 57-58.

10 Louis Petit de Julleville, Répertoire du théâtre comique en France au Moyen-Age (1886; rpt. Geneva: Slatkine Reprints, 1967).

11 Henri-Jean Martin, "What Parisians Read in the Sixteenth Century." In French Humanism: 1470-1600, ed. Werner L. Gundersheimer (New York: Harper \& Row, 1970), p. 140. This material was first edited in 1969.

12 Eugénie Droz, Le Recueil Trepperel, Les Sotties. .., pp. XLII-LXIII. See also Droz, Le Recueil Trepperel, fac-similé des trente-cinq pièces de l'original (Geneva: Slatkine Reprints, 1968), pp. 7-14 and Halina Lewicka, Le Recueil du British Museum, fac-similé. . . , p. XVIII.

13 Annie Parent, Les Métiers du livre à Paris au XVI siècle (1535-1560) (Geneva: Droz, 1974). Parent discusses these inheritance practices at great length.

14 Bowen, Les Caractéristiques essentielles. . . pp. 96-97.

15 Quoted in Howard Mayer Brown, Music in the French Secular Theatre, 1400-1550 (Cambridge, Mass.: Harvard Univ. Press, 1963), p. 6.

16 Eugénie Droz, Le Recueil Trepperel, Les Farces (Geneva: Droz, 1961), p. VII.

17 Robert Darnton, "Reading, Writing, and Publishing in Eighteenth-Century France: A Case Study in the Sociology of Literature," in Historical Studies Today, ed. Felix Gilbert and Stephen R. Graubard (New York: W.W. Norton and Co., 1972), p. 262. See also Robert M. Kingdon's "Patronage, Piety, and Printing in Sixteenth Century Europe," in Festschrift Frederick B. Artz, ed., David Pinckney and Theodore Ropp (Durham, N.C.: Duke Univ. Press, 1964), pp. 19-37. Kingdon discusses the sale of verriacular Bibles and Huguenot psalters by the Plantins.

18 A.H. Schutz, Vernacular Books in Parisian Private Libraries of the Sixteenth Century, according to the Notarial Inventories, Univ. of North Carolina Studies in the Romance Languages and Literatures, No. 25 (Chapel Hill: Univ. of North Carolina Press, 1955), pp. 31-73.

19 Petit de Julleville, Répertoire. . , p. 191.

20 Schutz, pp. 31-73.

21 Parent, Les Métiers du livre à Paris. . . , p. 49. Parent also identifies Longis and Janot among those who competed for the market in popular vernacular works although she fails to indicate that they printed popular drama.

22 Bowen, Les Caractéristiques essentielles. .., p. 197. Bowen lists the play as Les Droits de la porte Bodès.

23 Rudolph Hirsch, Printing, Selling and Reading: 1450-1550 (Wiesbaden: Otto Harrassowitz, 1967), p. 50.

24 Parent, Les Métiers. . , p. 106.

25 Jean-Pierre Seguin, L'Information en France, de Louis XII à Henri II (Geneva: Droz, 1961), p. 50 . 
26 Jean-Pierre Seguin, L'Information à la fin du XVe siècle en France, pièces d'actualité imprimées sous le règne de Charles VIII, in Arts et Traditions Populaires, 4 (1956) and 1 and 2 (1957), p. 316.

27 Seguin, L'Information à la fin du $X V^{e}$ siècle en France. . , p. 316.

28 Seguin, L'Information en France, de Louis XII à Henri II, p. 34.

29 Emmanuel Philipot, Six farces normandes du Recueil La Vallière (Rennes: Plihon, 1939), p. 21. This farce exists in two slightly different versions, one of which was published in the edition listed above. According to Philipot, this farce (which he thinks was written between 1515 and 1520) is the original, and the other, Les Trois Commères et un vendeur de livres, merely a revised version of it. There is no printed version of the play quoted here.

30 See Christopher P. Pinet, "The Cobbler in French Farce of the Renaissance," The French Review, 48 (1974), 308-320 for a discussion of one of these "cris."

31 Petit de Julleville, Répertoire. . , , p. 191.

32 François Rabelais, Le Tiers Livre, Ed. Pierre Jourda (Paris: Garnier, 1962), p. 547.

33 Philipot, Six farces normandes. . , , p. 21.

34 Alfred Franklin, Dictionnaire historique des arts, métiers et professions exercés dans Paris depuis le treizième siècle (1903: rpt. New York: Burt Franklin, 1968), pp. 180-181.

35 Philipot, p. 19.

36 Bowen, Les Caractéristiques essentielles. . . , p. 200.

37 For a full discussion see Droz, Le Recueil Trepperel, Les Sotties, pp. 147-150; 163; 180-183.

38 Bibl. nat., Rés. Ye 1361.

39 Bowen, pp. 96-97.

40 Henri-Jean Martin, "Culture écrite et culture orale, culture savante et culture populaire. ...," pp. 269-270. Martin, basing his argument on Marc Soriano's finding that the Perraults adapted fairy tales to the interests of a literate audience by eliminating notations intended for reading aloud, hypothesizes that much the same thing was done by storytellers who altered the contents of the printed versions held in their hands to suit the interests of their listeners.

41 Darnton, "Reading, Writing, and Publishing. . ., " p. 246.

42 Per Nykrog, Les Fabliaux: Etude d'histoire littéraire et de stylistique médiévale, Diss. Aarkus. 1959 (Copenhagen: Munksgaard, 1957). See also Jean Rychner's Contribution d l'étude des fabliaux: Variantes, remaniements, dégradations, Université de Neuchâtel, Recueil de travaux publiés par la Faculté des Lettres, XXVIII, 2 vols. I: Observations; II: Textes (Neuchâtel: Faculté des Lettres, Geneva: Libraire E. Droz, 1960) I, pp. 145-46. Rychner suggests that based on the number of variants, many of the fabliaux were destined for more popular audiences.

43 Charles Fourrier, L'Enseignement français de l'Antiquité à la Révolution (Paris: Institut Pédagogique National, 1964), pp. 136-37. See also Philippe Ariès, Centuries of Childhood, trans. Robert Baldick (New York: Random House, 1962), pp. 286-87.

44 George Huppert, "Public Schools in Renaissance France," p. 19. See also Ch. 7, "Schools" in Huppert's recent book, Les Bourgeois Gentilhommes: An Essay. . . , esp. pp. 62-71.

45 Huppert, "Public Schools. ...," p. 30.

46 Huppert, (bk.) pp. 59-83.

47 Hirsch, Printing, Selling and Reading: 1450-1550, p. 148.

48 François de Dainville, "Effectif des collèges et scolarité au XVII siècle dans le Nord-Est de la France," Population, 10 (1955), 477-489.

49 Ariès, Centureis of Childhood, p. 304. (Ariès has discussed a similar situation in Rouen in 1543.)

50 W.J. Frank Davies, Teaching Reading in Early England (London: Pitman Publishing, 1973), pp. 37-39. See also John William Adamson, "The Iliterate Anglo-Saxon" and other Essays on Education, Medieval and Modern (Cambridge, Eng.: Cambridge Univ. Press, 1946), pp. $40-41$. 
51 Roger Chartier, Dominique Julia and Marie-Madeleine Compère, L'Education en France du XVIe au XVIII siècle (Paris: Société d'Edition d'Enseignement Supérieur, 1976), pp. 3-4.

52 N.Z. Davis, Society and Culture in Early Modern France, cf. Chaps. 1, 2, 3, and 6. See also Davis' article "The Protestant Printing Workers of Lyons in 1551," in Aspects de la propagande religieuse, ed. Henri Meylan (Geneva: Droz, 1957), pp. 247-58. Robert Kingdon, "Patronage, Piety and Printing in Sixteenth-Century Europe." (See above for full reference.) Also Elizabeth L. Eisenstein, "L'avènement de l'imprimerie et la Réforme," Annales ESC, 26 (1971), 1355-1382.

53 Quoted from Hirsch, p. 152.

54 Bibl., nat., Rés. Ye 2717.

55 Eugénie Droz, Le Recueil Trepperel, fac-similé des trente-cinq pièces de l'original, p. 13, discusses one play, Grand voiage et pelerinage de saincte Caquette, which was composed in Caen for the students of one of the city's secondary schools. They later performed it; so the play served a pedagogical function. Halina Lewicka discusses the farces that treat children who are to go to school as well as the satire of Latin in the plays in "Histoire d'un thème dramatique: 'L'Enfant mis aux écoles,'" in Etudes sur l'ancienne farce française (Paris: Klincksieck, 1974), pp. 32-46. L.V. Gofflot also gives evidence of the performance of vernacular plays by school children in Le Théâtre au Collège du Moyen Age d̀ nos jours (Paris: Champion, 1907), pp. 26-31. The plays may have had an impact on the reading habits of the children although the extent of the impact cannot be measured.

56 Chartier, L'Education en France du XVIe au XVIIIe siècle, p. 213.

57 See above, p. 5, 11. 4-6; below, p. 25.

58 W.J. Frank Davies, Teaching Reading in Early England, p. 37.

59 Elizabeth L. Eisenstein, "The Advent of Printing and the Problem of the Renaissance," Past and Present, 45 (Nov. 1969), 66.

60 Quoted by Hirsch, p. 135.

61 Walter Ong, The Presence of the Word, p. 30.

62 Robert M. Gagné, The Conditions of Learning (New York: Holt, Rinehart \& Winston, 1970), p. 272.

63 Walter Ong, "The Writer's Audience is Always a Fiction," PMLA, 90 (1975), 12.

64 Ibid., p. 14.

65 See R.S. Schofield, “The Measurement of Literacy in Pre-Industrial England," in J.R. Goody, ed., Literacy in Traditional Societies (Cambridge, Eng.: Cambridge Univ. Press, 1968), pp. 213-14.

66 Davies, Teaching Reading in Early England, pp. 92-93.

67 Ibid., pp. 92-93.

68 Henri-Jean Martin, "Culture écrite et culture orale, culture savante et culture populaire. .. ," p. 232.

69 Parent, Les Métiers du livre. . . , pp. 209-216.

70 A. Labarre, Le Livre dans la vie amiénoise du seizième siècle. L'enseignement des inventaires après décès (1503-1576) (Paris: 1971), pp. 362-365.

71 Howard Mayer Brown, Music in the French Secular Theatre, 1400-1550 (Cambridge, Mass.: Harvard Univ. Press, 1963), p. 83.

72 Elizabeth L. Eisenstein, "The Advent of Printing and the Problem of the Renaissance," p. 30 .

73 Ibid., p. 31.

74 Robert Kingdon, "Patronage, Piety, and Printing in Sixteenth-Century Europe," pp. 27-28. 75 Bowen, Les Caractéristiques essentielles. . . , pp. 45-47.

76 David T. Pottinger, The French Book Trade in the Ancien Régime: 1500-1791 (Cambridge, Mass.: Harvard Univ. Press, 1958), p. 19. Pottinger discusses the increasing pressure to make French the language of the realm.

77 See above and also Natalie Davis' "Proverbial Wisdom and Popular Errors," in Society and Culture in Early Modern France, pp. 227-67. 
132 / Renaissance and Reformation
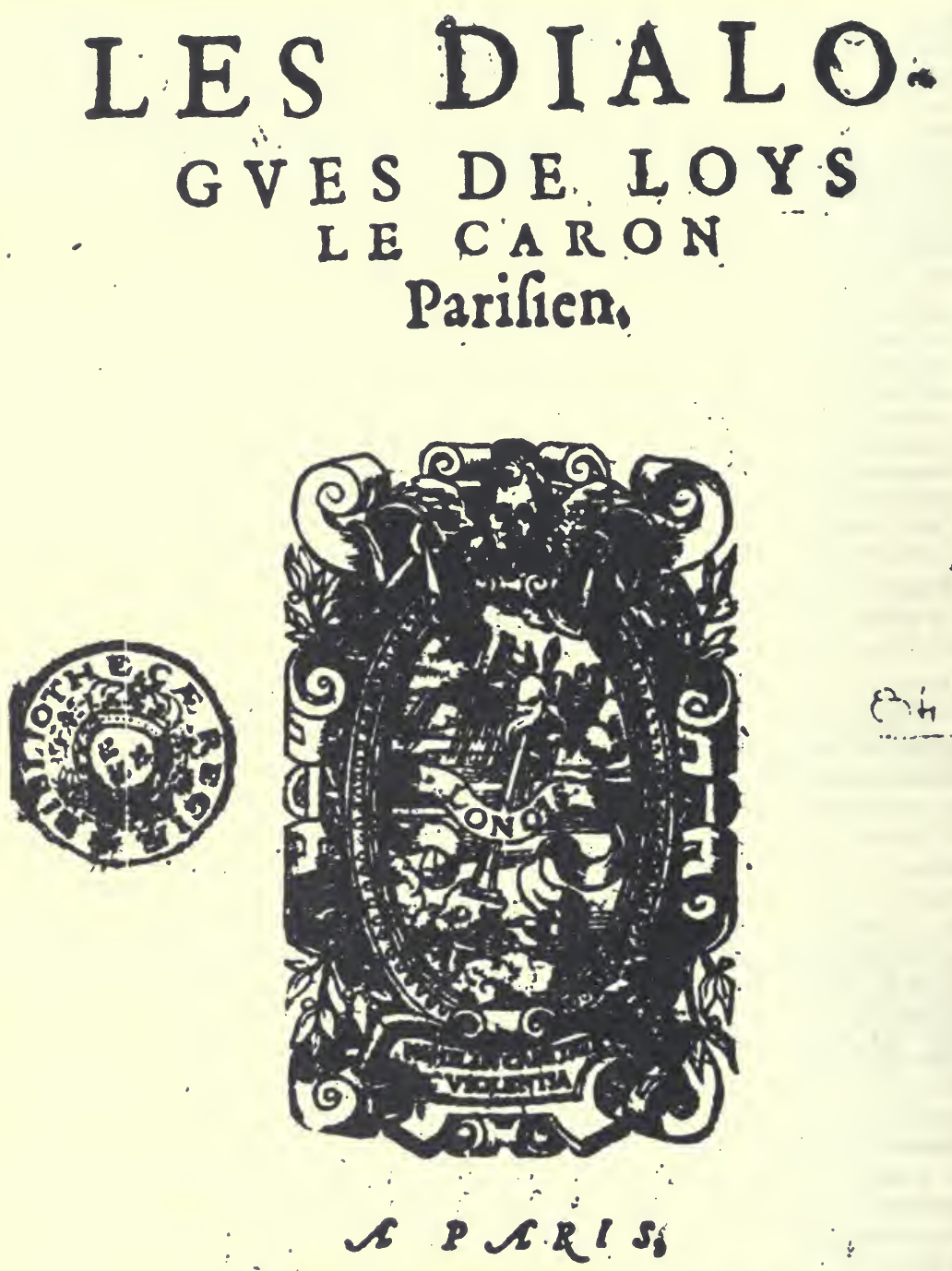

2A Pourleas Long is Libraire, scument fo bourigue en la galleriespar oi

i. Loid va a la Chancellicioio:

$$
\begin{aligned}
& \text { I } 5.5 \% \\
& \text { Auec Privilege. }
\end{aligned}
$$

